\title{
SYNTHETIC MOISSANITE: A NEW DIAMOND SUBSTITUTE
}

By Kurt Nassau, Shane F. McClure, Shane Elen, and James E. Shigley

A new diamond imitation, synthetic moissanite (silicon carbide), is now being produced by C3 Inc. in near-colorless form for jewelry purposes. With refractive indices of 2.648 and 2.691, a dispersion of 0.104, a hardness of $91 / 4$ on the Mohs scale, and a specific gravity of 3.22, synthetic moissanite is much closer to diamond in overall appearance and heft than any previous diamond imitation. The thermal properties of synthetic moissanite are also so close to those of diamond that the thermal probes currently on the market react to synthetic moissanite as if it were "diamond." This new material can be readily separated from diamond on the basis of its anisotropic optical character, which produces a doubling in the appearance of facet junctions. A new instrument manufactured by C3 Inc. solely to distinguish synthetic moissanite from diamond was also examined for this study.

\section{ABOUT THE AUTHORS}

Dr. Nassau, retired from his position as Distinguished Scientist at AT\&T Bell Laboratories, is now a freelance writer, consultant, and expert witness living in Lebanon, New Jersey. He is on the Board of Directors of C3 Inc. Mr. McClure is manager of Identification Services at the GIA Gem Trade Laboratory, Carlsbad, California. Mr. Elen is a research technician, and Dr. Shigley is director, at GIA Research, Carlsbad.

Please see acknowledgments at end of article. Gems \& Gemology, Vol. 33, No. 4, pp. 260-275

(C) 1997 Gemological Institute of America o the long list of diamond simulants currently available in the jewelry market, a new one has been added: synthetic moissanite. As typically happens with the introduction of a synthetic or simulant, there is considerable concern in the jewelry trade about this diamond imitation and its identification. One particular problem with synthetic moissanite is that its thermal properties are so close to those of diamond that it passes as "diamond" when tested with a thermal probe.

This article reports on the examination of several samples of near-colorless synthetic moissanite (figure 1), both to characterize this material and to determine how it can be identified by standard gem-testing methods. The authors also evaluate a testing instrument developed by C3 Inc., which is intended to be used in conjunction with a thermal probe to distinguish this new simulant from diamond.

\section{BACKGROUND}

Diamond Imitations. All diamond imitations known to date have significant deficiencies. For example, synthetic spinel, colorless sapphire, and YAG (yttrium aluminum garnet) are much less brilliant than diamond. Synthetic rutile and strontium titanate are much too soft and display too much dispersion ("fire"). GGG (gadolinium gallium garnet) and CZ (cubic zirconia) have very high specific gravities, and the latter is somewhat brittle. Synthetic moissanite, by contrast, has gemological properties that are generally closer to those of diamond (table 1).

Silicon Carbide. Since it was first manufactured a century ago, silicon carbide $(\mathrm{SiC})$ has played an important industrial role as an abrasive. The growth of single crystals of silicon carbide has been studied for many years for two possible end uses: as a semiconductor material, and as a diamond substitute in jewelry. In fact, the promise of synthetic moissanite as a diamond imitation has been described several times in the gemological and related literature. Some of these publications included enthusiastic descriptions of faceted colored material (usually blue to green) and premature claims that 
Figure 1. Near-colorless synthetic moissanite is being marketed for jewelry purposes as a diamond imita-

tion. The faceted pieces shown here, weighing from 0.09 to $0.57 \mathrm{ct}$, illustrate the appearance of this material. Because synthetic moissanite is doubly refractive, one

can sometimes see doubling of the back facet junctions even with the unaided eye (particularly noticeable in the large round brilliant on the upper right). Photo (C) GIA and Tino Hammid.
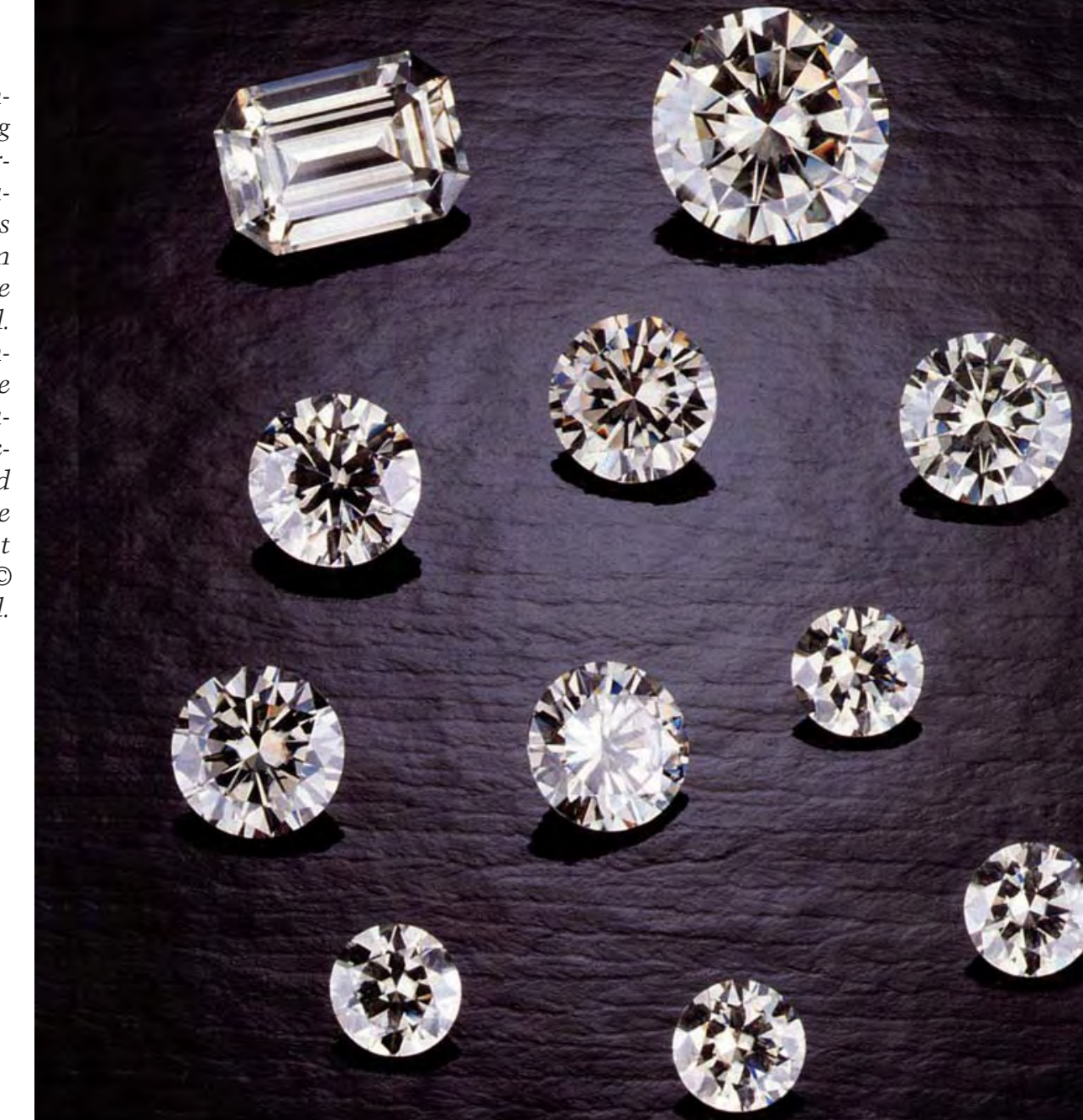

Durham, North Carolina, and distributed by C3 Inc. A preliminary note on the new C3 material has appeared in this journal (Johnson and Koivula, 1996).

Early work on silicon carbide was summarized

colorless material was available (see, e.g., De Ment, 1948, 1949; Mitchell, 1962; McCawley, 1981). One of the authors $(\mathrm{KN})$ noted the potential value of silicon carbide as a gem simulant 17 years ago. Referring to some pale tan to green to black centimeter-size crystals and faceted stones as large as half a carat, he stated that "these synthetic moissanites are quite attractive, and might provide a superb diamond imitation if they could only be made colorless" (Nassau, 1980, p. 253). At that time, however, a way had not been found to control either the color or the growth process to make synthetic crystals suitable for the gem industry.

Only recently, as described below, has the controlled growth of synthetic moissanite actually been achieved. Material that may appear near-colorless face-up in jewelry is now available for gemological use. It is being produced by Cree Research Inc. of by Mellor (1929; see also Powell, 1956). Edward G. Acheson (1893) appears to have been the first to recognize its hardness and potential as an abrasive. He made silicon carbide accidentally while trying to grow diamond by passing an electric arc between carbon electrodes through a mixture of carbon and molten clay (an aluminum silicate). He named the new substance "carborundum" (later to become a trade name). Subsequently, he obtained a better yield by using a mixture of carbon and sand. This same "Acheson" process is still used today in slightly modified form for the manufacture of silicon carbide for abrasive products (Divakar et al., 1993).

Shortly thereafter, the Nobel prize-winning 
TABLE 1. Characteristics of "colorless" diamond and "colorless" simulants.

\begin{tabular}{|c|c|c|c|c|c|c|c|c|}
\hline Materiala & $\begin{array}{l}\text { Mohs } \\
\text { hardness }\end{array}$ & Toughness & R.I. & Birefringence & Dispersion & S.G. & Optic character & $\begin{array}{l}\text { Pavilion } \\
\text { flash colors }\end{array}$ \\
\hline Diamond & 10 & $\begin{array}{l}\text { Good to } \\
\text { excellent }\end{array}$ & 2.417 & None & $\begin{array}{c}0.044 \\
\text { (moderate) }\end{array}$ & 3.52 & $\begin{array}{l}\text { Singly refractive } \\
\text { (isotropic) }\end{array}$ & $\begin{array}{l}\text { Orange and blue } \\
\text { on a few facets }\end{array}$ \\
\hline Syn. moissanite & $9 \frac{1}{4}$ & Excellent & $\begin{array}{l}2.648 \\
2.691\end{array}$ & $\begin{array}{c}0.043 \\
\text { (moderate) }\end{array}$ & $\begin{array}{c}0.104 \\
\text { (strong) }\end{array}$ & $3.22^{\mathrm{c}}$ & $\begin{array}{l}\text { Doubly refractive } \\
\text { (uniaxial }+ \text { ) }\end{array}$ & Orange and blue \\
\hline Syn. corundum & 9 & Excellent & $\begin{array}{l}1.770 \\
1.762\end{array}$ & $\begin{array}{l}0.008- \\
0.010 \\
\text { (weak) }\end{array}$ & $\begin{array}{l}0.018 \\
\text { (weak) }\end{array}$ & 4.00 & $\begin{array}{l}\text { Doubly refractive } \\
\text { (uniaxial -) }\end{array}$ & Not diagnostic \\
\hline Cubic zirconiad & $8-8 \frac{1}{2}$ & Good & $\begin{array}{l}2.150- \\
2.180\end{array}$ & None & $\begin{array}{c}0.058- \\
0.066 \\
\text { (moderate) }\end{array}$ & $\begin{array}{l}5.56- \\
6.00\end{array}$ & $\begin{array}{l}\text { Singly refractive } \\
\text { (isotropic) }\end{array}$ & $\begin{array}{c}\text { Orange over most } \\
\text { of pavilion }\end{array}$ \\
\hline $\begin{array}{l}\text { Yttrium aluminum } \\
\text { garnet (YAG) }\end{array}$ & $8^{\frac{1}{4}}$ & Good & 1.833 & None & $\begin{array}{c}0.028 \\
\text { (weak) }\end{array}$ & 4.55 & $\begin{array}{l}\text { Singly refractive } \\
\text { (isotropic) }\end{array}$ & $\begin{array}{l}\text { Blue, violet, some } \\
\text { orange }\end{array}$ \\
\hline Syn. spinel & 8 & Good & 1.728 & None & $\begin{array}{l}0.020 \\
\text { (weak) }\end{array}$ & 3.64 & $\begin{array}{l}\text { Singly refractive } \\
\text { (isotropic) }\end{array}$ & $\begin{array}{c}\text { Blue over most of } \\
\text { pavilion }\end{array}$ \\
\hline $\begin{array}{l}\text { Gadolinium gallium } \\
\text { garnet (GGG) }\end{array}$ & n $\quad 6^{\frac{1}{2}}$ & Fair to good & 1.970 & None & $\begin{array}{c}0.045 \\
\text { (moderate) }\end{array}$ & 7.05 & $\begin{array}{l}\text { Singly refractive } \\
\text { (isotropic) }\end{array}$ & $\begin{array}{l}\text { Blue, some } \\
\text { orange }\end{array}$ \\
\hline Syn. rutile & $6-6^{\frac{1}{2}}$ & Poor to fair & $\begin{array}{l}2.616 \\
2.903\end{array}$ & $\begin{array}{l}0.287 \\
(v . \text { strong)e }\end{array}$ & $\begin{array}{c}0.330 \\
\text { (v. strong) }\end{array}$ & 4.26 & $\begin{array}{l}\text { Doubly refractive } \\
\text { (uniaxial +) }\end{array}$ & $\begin{array}{l}\text { Various spectral } \\
\text { colors, widespread }\end{array}$ \\
\hline Strontium titanate & $5-6$ & Fair & 2.409 & None & $\begin{array}{c}0.190 \\
\text { (v. strong) }\end{array}$ & 5.13 & $\begin{array}{l}\text { Singly refractive } \\
\text { (isotropic) }\end{array}$ & $\begin{array}{l}\text { Spectral colors, } \\
\text { widespread }\end{array}$ \\
\hline
\end{tabular}

References: GIA Gem Property Chart A (1992), GIA Gem Reference Guide (1988), Harris (1995), Hobbs (1981), Nassau (1980), von Muench (1982), and this study.

aGlass and colorless minerals, such as zircon, topaz, and quartz, are not included in this table because they are rarely encountered today.

${ }^{b}$ All but one sample of synthetic moissanite were inert to short-wave UV radiation.

chemist Henri Moissan discovered natural silicon carbide in the Canyon Diablo meteorite (Moissan, 1904). Kunz (1905) applied the name moissanite to the natural mineral in Moissan's honor.

Since then, moissanite reportedly has been found in tiny amounts in other meteorites as well as in many terrestrial occurrences (e.g., Obukhov, 1972; Vigorova et al., 1978; Hallbauer et al., 1980; Moore et al., 1986; Rodgers et al., 1989; Mathez et al., 1995). Some or all of these occurrences may have been spurious, with the material derived from the older cutting wheels used to section mineral, rock, and meteorite specimens (Mason, 1962; Milton and Vitaliano, 1984; Milton, 1986), or from contamination by the huge amounts of silicon carbide produced industrially. (More than 36,000 tons were produced domestically, and 159,000 tons were imported into the United States, during the first seven months of 1997 [Balaziak, 1997].) However, the identification of moissanite as inclusions in diamond crystals before they were broken (Moore et al., 1986), and the determination of their abnormal isotopic composition (Mathez et al., 1995), confirm the occurrence of moissanite as a natural mineral.
The Structure of Moissanite. At first, considerable confusion resulted when investigators found a variety of different crystal structures for moissanite, including those having cubic $(\mathrm{C})$, hexagonal $(\mathrm{H})$, and rhombohedral (R) symmetries. This complexity results from the existence of polytypes, which represent different stacking sequences of hexagonal layers of atoms. More than 150 polytypes are known in the case of silicon carbide, all of which are properly designated as "moissanite" (Thibault, 1944; Ramsdell, 1947; Verma and Krishna, 1966).

At present, only the $4 \mathrm{H}$ and $6 \mathrm{H}$ polytypes of alpha-SiC can be grown in bulk form (i.e., as boules). Both polytypes are hexagonal, and both yield near-colorless material. The near-colorless synthetic moissanite described here is the $6 \mathrm{H}$ form. The $4 \mathrm{H}$ polytype, which has properties very close to those of the $6 \mathrm{H}$ polytype, is currently being produced for semiconductor uses, but not in near-colorless form. A key distinction from the $6 \mathrm{H}$ polytype is the much weaker absorption below $425 \mathrm{~nm}$ in the visible spectrum (Harris, 1995). Beta-SiC, which is the $3 \mathrm{C}$ polytype, is cubic and has a crystal structure even closer to that of diamond than the $4 \mathrm{H}$ or $6 \mathrm{H}$ 


\begin{tabular}{|c|c|c|c|c|c|}
\hline $\begin{array}{l}\text { Long-wave UV } \\
\text { fluorescenceb }\end{array}$ & Absorption spectrum & Polish luster & $\begin{array}{l}\text { Read-through } \\
\text { effect }\end{array}$ & $\begin{array}{l}\text { Relief in } 3.32 \\
\text { S.G. liquid }\end{array}$ & Magnification \\
\hline $\begin{array}{l}\text { Inert or } \\
\text { (usually) blue; } \\
\text { sometimes yellow }\end{array}$ & $\begin{array}{l}\text { "Cape" lines at } 415 \text { and } \\
478 \text { nm, sometimes no } \\
\text { sharp lines }\end{array}$ & Adamantine & None & High & $\begin{array}{l}\text { Included crystals, feathers, graining, } \\
\text { bearding, naturals, waxy to granular girdle } \\
\text { surface, sharp facet junctions }\end{array}$ \\
\hline Inert to orange & $\begin{array}{l}\text { Absorption below } \\
425 \mathrm{~nm} \text {; no sharp } \\
\text { lines }\end{array}$ & Subadamantine & None & High & $\begin{array}{l}\text { Doubling in appearance of facet junctions, } \\
\text { whitish or reflective needles, rounded } \\
\text { facet junctions, surface pits, polish lines }\end{array}$ \\
\hline Inert & Not diagnostic & $\begin{array}{l}\text { Vitreous to } \\
\text { subadamantine }\end{array}$ & Very strong & Moderate & Gas bubbles, sharp facet junctions \\
\hline $\begin{array}{l}\text { Greenish yellow or } \\
\text { yellowish orange }\end{array}$ & Not diagnostic & Subadamantine & Slight & Moderate & $\begin{array}{l}\text { Gas bubbles, unmelted zirconium } \\
\text { oxide powder, sharp facet junctions }\end{array}$ \\
\hline $\begin{array}{l}\text { Orange, sometimes } \\
\text { inert }\end{array}$ & Not diagnostic & $\begin{array}{l}\text { Subadamantine } \\
\text { to vitreous }\end{array}$ & Strong & Low & Gas bubbles, sharp facet junctions \\
\hline Weak green or inert & Not diagnostic & $\begin{array}{l}\text { Vitreous to } \\
\text { subadamantine }\end{array}$ & Very strong & Low & Gas bubbles \\
\hline $\begin{array}{l}\text { Pinkish orange } \\
\text { or inert }\end{array}$ & Not diagnostic & $\begin{array}{l}\text { Adamantine to } \\
\text { vitreous }\end{array}$ & Moderate & Low & $\begin{array}{l}\text { Gas bubbles, metallic platelets, rounded } \\
\text { facet junctions, polishing marks }\end{array}$ \\
\hline Inert & $\begin{array}{l}\text { Absorption below } \\
430 \mathrm{~nm}\end{array}$ & $\begin{array}{l}\text { Subadamantine } \\
\text { to submetallic }\end{array}$ & None & High & $\begin{array}{l}\text { Doubling in appearance of facet junctions, } \\
\text { gas bubbles, rounded facet junctions, } \\
\text { polishing marks }\end{array}$ \\
\hline Inert & Not diagnostic & $\begin{array}{l}\text { Vitreous to } \\
\text { subadamantine }\end{array}$ & None & High & $\begin{array}{l}\text { Gas bubbles, rounded facet junctions, } \\
\text { polishing marks, scratches, abrasions }\end{array}$ \\
\hline
\end{tabular}

cSynthetic moissanite will float in methylene iodide (S.G. 3.32), while diamond and the other diamond imitations listed in this table will sink. ¿Cubic zirconia varies in chemical composition, so the properties will vary somewhat.

ev. strong = very strong.

polytypes. However, it cannot be grown in bulk form at present and it is inherently yellow (von Muench, 1982).

Single Crystal (Bulk) Growth of Synthetic Moissanite. Growth techniques for silicon carbide have been studied for many decades $\left(\mathrm{O}^{\prime}\right.$ Connor and Smiltens, 1960; Verma and Krishna, 1966; Smoak et al., 1978; von Muench, 1984; Wilke, 1988; Davis et al., 1990; Divakar et al., 1993). Of these, only a seeded sublimation process, derived from the "Lely" approach, has proved viable for the controlled growth of large single crystals of synthetic moissanite (Davis et al., 1990; Nakashima et al., 1996).

In his original work, Lely (1955) used a cylinder, made of lumps of $\mathrm{SiC}$, that had a cavity. This cylinder was heated in a sealed graphite crucible to $2500^{\circ} \mathrm{C}$, at which point $\mathrm{SiC}$ crystals grew inside the cavity. Difficulties with controlling the chemical purity and the specific polytypes formed have led to many modifications. In particular, the use of carefully controlled atmospheres and temperature gradients, as well as the addition of a thin, porous graphite tube to line the cavity (which, through dif- fusion, provides improved control of the sublimation) have resulted in better control of the crystals that grow inside the tube. Many types of heating systems have been used, including radio frequency and resistance heating. Significant advances in the Lely process were reported in the USSR (Tairov and Tsvetkov, 1981).

The final breakthrough in the Lely process is revealed in a patent of Davis et al. (1990), where controlled growth of $\mathrm{SiC}$ occurs by sublimation from a feed powder, diffusion through graphite, and growth directly from the vapor phase on a seed crystal. With a sublimation process, the silicon carbide vaporizes and then recrystallizes without ever passing through a liquid stage. Details of this growth process as used for the near-colorless synthetic moissanite being distributed by C3 Inc. have not been released.

However, Davis et al. (1990) reported the growth of a $6 \mathrm{H}$-polytype synthetic moissanite crystal (of gem quality, but not colorless) that was 12 $\mathrm{mm}$ in diameter and $6 \mathrm{~mm}$ thick during a six-hour growth period at the time of the initial patent filing in 1987. One of many recent papers in Nakashima 
et al. (1996), on various aspects of synthetic moissanite growth and its applications to the electronics industry by Cree Research, mentions the availability of $50-\mathrm{mm}$-diameter boules of $6 \mathrm{H}$ moissanite in 1994 (Tsvetkov et al., 1996). Such a boule could conceivably permit the manufacture of a brilliant-cut synthetic moissanite $50 \mathrm{~mm}$ in diameter and $28 \mathrm{~mm}$ high that would weigh about 380 carats! No production figures have been released on the amount of material that is currently available or could be made available for jewelry purposes. However, in December 1997, the senior author saw more than 1,000 faceted synthetic moissanites in the offices of C3 Inc. The company has stated that it plans to focus its marketing on near-colorless faceted material, with a release to the trade in early 1998 , in a price range of $5 \%-10 \%$ of the average retail price of comparable diamonds (J. Hunter, pers. comm., 1997).

The hardness of synthetic moissanite is listed as $9^{1 / 4}$ on the Mohs scale, which may be misleading. As shown in figure 2, the Mohs scale above a hardness value of 8 is disproportionately compressed when compared to a quantitative linear hardness scale such as that of Knoop (Bruton, 1978), which measures indentation hardness. The Knoop hardness of the $6 \mathrm{H}$ polytype of moissanite is reported to be in the range $2917-2954 \mathrm{~kg} / \mathrm{mm}^{2}(2.91-2.95 \mathrm{Gpa})$ on the $c$ crystal face (von Muench, 1984). The difference in Knoop hardness between corundum (Mohs 9) and moissanite (Mohs $9^{11 / 44}$ ) is larger than the difference between corundum and topaz (Mohs 8). Because of this disparity, synthetic moissanite cannot be polished by conventional techniques. The complex cutting process requires an additional, proprietary step (J. Hunter, pers. comm., 1997).

\section{MATERIALS AND METHODS}

Twenty-three faceted "near-colorless" synthetic moissanites were made available to GIA by C3 Inc. for this study; we had requested a representative range of the colors and qualities that could be produced. The samples weighed from 0.09 to $1.12 \mathrm{ct}$, and were polished in round brilliant, emerald cut, and square-modified-brilliant styles. In addition, C3 Inc. supplied a 3.79 ct polished rectangular light green piece that had been optically oriented for spectroscopy. A 71.4 gram piece of boule and two 7 $\mathrm{mm}$ cubes were used for a precise specific gravity determination and a cleavage experiment. (However, C3 Inc. has stated that rough material will not be available to the trade for the time being.)

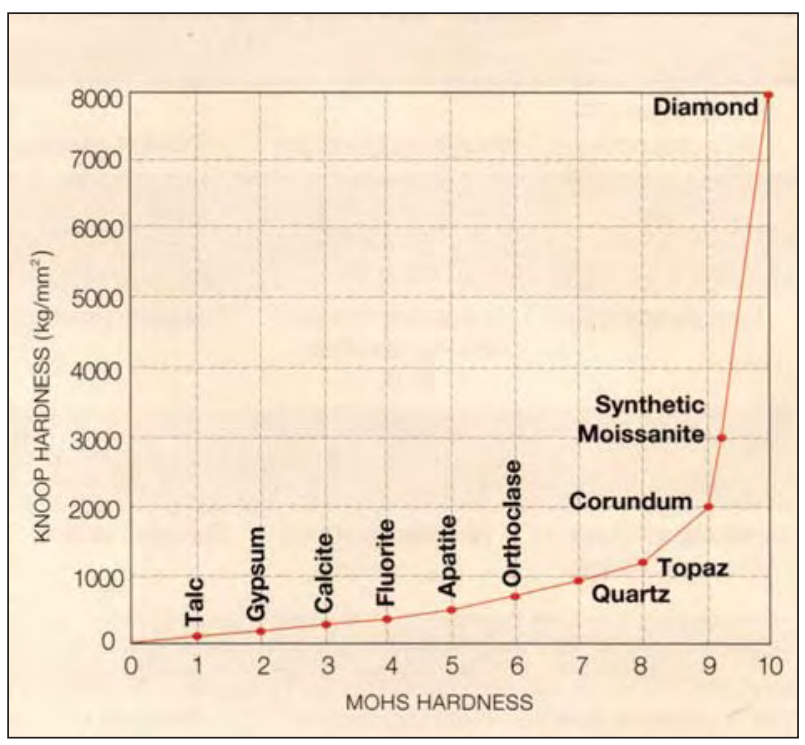

Figure 2. This diagram compares the Mohs and Knoop (indentation) hardness scales. The Knoop scale better illustrates the relationship in hardness for diamond, synthetic moissanite, and corundum. Diagram modified after Bruton, 1978, p. 402.

In addition to the samples studied at GIA, one of the authors (KN) examined approximately 1,000 faceted synthetic moissanites and 100 preformed cubes at C3 Inc. The faceted samples included a $4.92 \mathrm{ct}$ round brilliant, with a diameter of $11.9 \mathrm{~mm}$ and an approximate color grade of $\mathrm{N}$, and a green round brilliant of $17.31 \mathrm{ct}$ with a diameter of 17.5 $\mathrm{mm}$. The faceted pieces studied at GIA were representative of this larger group of cut stones examined at C3 Inc. Also seen were 13 pieces of jewelry, which contained a total of 38 stones and included the ring discussed below.

Standard gemological equipment used for all 23 main samples included a Gemolite Mark V binocular microscope, a polariscope, a desk-model spectroscope, and a short-wave $(254 \mathrm{~nm})$ and long-wave (365 nm) ultraviolet lamp. Approximate refractive index values were measured for 11 of these samples with a Jemeter Digital 90 infrared reflectometer. For research purposes only (the GIA Gem Trade Laboratory does not grade diamond simulants), trained graders used standard GTL procedures to try to assign diamond-equivalent color grades to the 18 samples that weighed more than $0.20 \mathrm{ct}$. Specific gravity measurements were obtained by the hydrostatic method on these same 18 samples, as well as the large piece of rough described above.

Because the thermal inertia ranges of diamond $\left(0.55-1.7 \mathrm{cal} / \mathrm{cm}^{\circ} \mathrm{C}\right)$ and moissanite $(1.6-4.8 \mathrm{cal} / \mathrm{cm}$ ${ }^{\circ} \mathrm{C}$ ) overlap (Hoover, 1983; Harris, 1995), GIA 
researchers performed thermal inertia testing on the 23 core samples using a Ceres CZeckpoint, a Ceres Diamond Probe II, a GIA GEM DiamondMaster, and a GIA GEM Mini-DiamondMaster. For comparison, the following "colorless" gem materials were also tested using the same four instruments (with the number of samples in parentheses): diamond (types Ia [5 samples] and IIa [1]), sapphire (3), zircon (2), cubic zirconia (2), strontium titanate (2), synthetic spinel (2), synthetic rutile (7), yttrium aluminum garnet (2), gadolinium gallium garnet (2), "paste" (glass-2), and quartz (1). Thirteen colorless to yellow diamonds, with color grades ranging from E to Fancy Light Yellow, were also tested with the GIA Gem DiamondMaster. The senior author made thermal inertia measurements on 10 additional synthetic moissanites with a Ceres CZeckpoint, a Ceres Diamond Probe, a Presidium tester, and a Diamond Guard. Electrical conductivity of the 23 main synthetic moissanite samples was measured using a GIA GEM Instruments conductometer.

The ultraviolet transparency of a diamond was compared to that of several synthetic moissanites in a specially designed viewing box, using a concept similar to that suggested by Yu and Healey (1980). $\mathrm{X}$-ray transparency was recorded photographically using an HP Faxitron X-ray machine. Visual observation of the luminescence to X-rays of both materials (one diamond and 11 synthetic moissanites) was performed with a Picker portable X-ray unit adapted for this purpose.

Semiquantitative chemical analysis of eight of the synthetic moissanites examined at GIA was performed with a Tracor Spectrace 5000 energy-dispersive X-ray fluorescence (EDXRF) system. Several sets of excitation conditions were used to detect the widest possible range of chemical elements. Operating conditions yielded a lower limit of detection for transition metals of about 0.01 wt. \%.

Absorption spectra for eight of the GIA samples were obtained in the ultraviolet-visible range $(250-750 \mathrm{~nm})$ at room temperature using a Hitachi U4001 spectrophotometer, and in the infrared range using a Nicolet Magna 550 spectrometer. Raman spectra were recorded with a Renishaw System 2000 instrument. For details on any of these experimental procedures, please contact the GIA authors.

A small instrument has been developed by C3 Inc. for the specific and limited purpose of distinguishing synthetic moissanite from diamond (see figure 3). Marketing of the Colorless Moissanite/ Diamond Tester Model 590 is expected to start early in 1998, at approximately the same time that synthetic moissanite is released to the jewelry trade (J. Hunter, pers. comm., 1997).

The C3 tester determines relative transparency in the near-ultraviolet, where diamond transmits and synthetic moissanite absorbs. The accompanying instructions clearly state that this new instrument is to be used only in conjunction with a standard thermal inertia tester. Any unknown near-colorless gem should first be tested with a thermal inertia probe. Only those samples that the thermal inertia tester indicates are "diamond" would need to be tested with the C3 instrument, which would then identify whether any were synthetic moissanite. With the C3 instrument, the gem sample is illuminated at an angle by a small, high-intensity halogen lamp. Radiation from the lamp is transmitted and reflected within the sample, and the near-ultraviolet radiation that emerges from the table facet is detected by the instrument.

Use of the instrument is fairly simple. The operator brings the polished facet of a diamond or synthetic moissanite (loose or mounted) in contact with a fiber-optic probe that is located on the side of the instrument. As soon as the sample touches the probe, the instrument emits a sound (and an indicator light illuminates) if any material other than moissanite is detected; there is no sound or response from the indicator light if the item is synthetic moissanite. The synthetic moissanites, dia-

Figure 3. The Colorless Moissanite/Diamond Tester Model 590 was designed and built by C3 Inc. for the sole purpose of rapidly distinguishing synthetic moissanite from diamond only after a stone has been identified as "diamond" on a thermal probe. Photo by Maha DeMaggio.

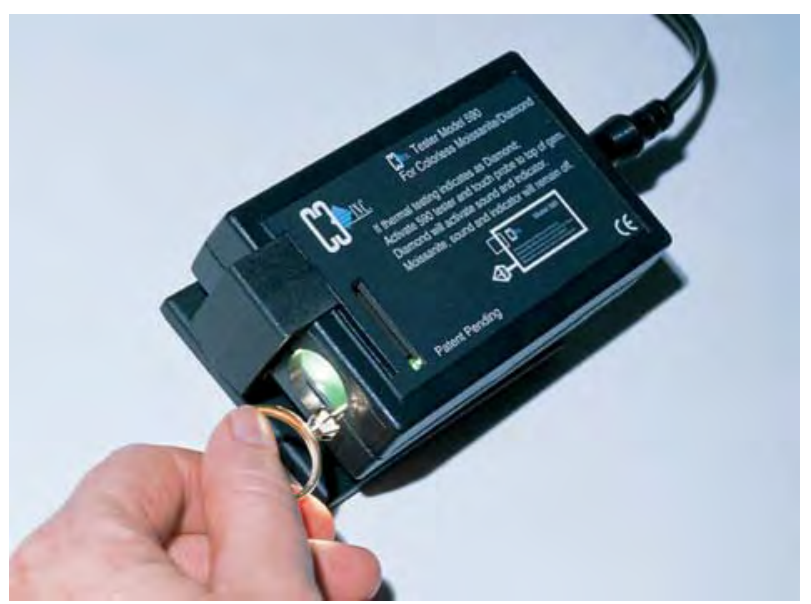




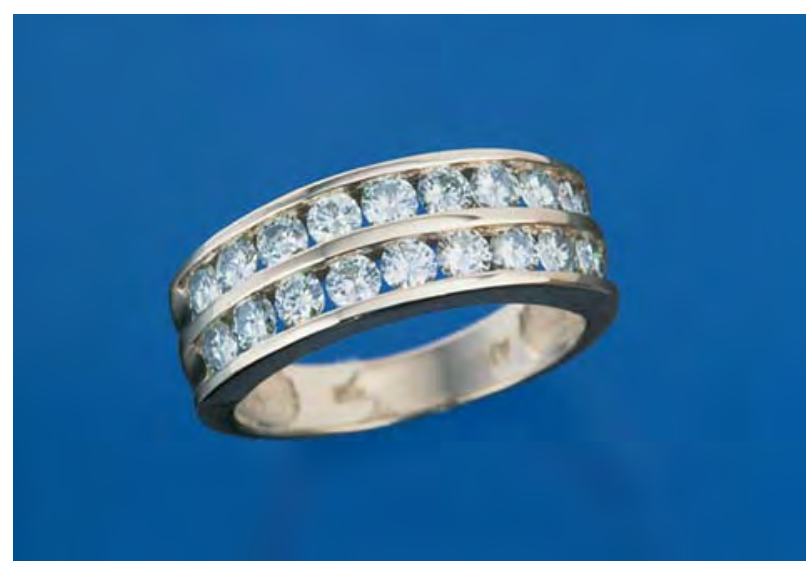

Figure 4. This $14 \mathrm{k}$ gold ring contains two rows of faceted light-green synthetic moissanites, which were mounted in wax and then cast in place with no apparent damage to the material. All of the stones reacted as synthetic moissanite on the Model 590 tester. Ring courtesy of C3 Inc.; photo by Maha DeMaggio.

monds, and other near-colorless gem materials listed above for the thermal probe testing were also tested with this instrument. In addition, the C3 instrument was used to test 13 pieces of jewelry containing synthetic moissanites, including the ring in figure 4.

\section{RESULTS}

Table 2 summarizes some of the gemological properties-i.e. those data that were found to vary from one sample to the next-of the 23 synthetic moissanites examined in detail during this study.

Visual Appearance. The samples examined at GIA (reportedly representing the range of color that can be produced at present) were near-colorless to light yellow, green, and gray. Those samples that appeared to be in the I-to-K range all looked colorless in the face-up position, but around the L-to-N range they started to show face-up color. The one U-V stone was obviously gray face-up, which made it appear dark. Because many of these samples had grayish or greenish hues, it was difficult to arrive at an exact color grade on the traditional D-to-Z scale, which is comprised of predominantly yellowish stones. In the color grading of diamonds, grayish or greenish hues such as these fall outside normal procedures. However, when compared to diamonds that do fall on the D-to-Z scale, the 18 faceted synthetic moissanites above $0.20 \mathrm{ct}$ ranged from the lower end of the "near-colorless" (G-to-J) category, with the best color being equivalent to $\mathrm{I}$, to $\mathrm{U}-\mathrm{V}$ in the "light" category of the scale. Synthetic moissan- ites representing this approximate range of colors are illustrated in figure 5 .

At first overall observation with the unaided eye, this material looks like a believable diamond imitation (see again figure 1). There were no eye-visible inclusions in any of the samples (on the diamond clarity grading scale, these synthetic moissanites would fall into the VVS to SI grades). They displayed no "read-through" effect, as can be seen in most other diamond imitations, which have lower refractive indices (see Hobbs, 1981). The samples showed moderate to high dispersion (greater than that of diamond or $\mathrm{CZ}$, but less than that of synthetic rutile). Their brilliance appeared to be slightly less than that of diamond.

Gemological Properties. The refractive indices of synthetic moissanite are over the limit of a conventional refractometer (that is, greater than 1.81). Measurements with the Jemeter reflectivity meter revealed an R.I. range of 2.59-2.64. Refractive index values of $\omega=2.648$ and $\varepsilon=2.691$ (with a birefringence of 0.043 and dispersion of 0.104 ) have been measured using precision optical techniques on synthetic moissanite (von Muench, 1982; Harris, 1995).

When they were observed under crossed polarizers in a polariscope, all of the synthetic moissanites remained dark when rotated in a face-down position. This singly refractive reaction is to be expected, since all of the samples were oriented with the c-axis (optic axis) perpendicular to the table facet. These samples had to be examined in several directions, most notably through the girdle, to obtain a doubly refractive reaction. Checking stones in several orientations in the polariscope is a wise precaution in any case, but it is particularly important for the separation of synthetic moissanite from diamond (which is singly refractive in all orientations). We did obtain a uniaxial optic interference figure in most of the samples (although with some difficulty), and we did not observe any strain pattern such as might be seen in diamond.

The hydrostatic specific gravity measurements ranged from 3.20 to 3.24 (again, see table 2), which is significantly lower than the 3.52 value typical of diamond. A precision density performed on the 71.4 gram piece of rough gave a value of 3.224. Because of the difference in specific gravity, a diamond and a synthetic moissanite faceted as round brilliants of the same diameter and the same proportions will have different carat weights (e.g., a 6.50-mm-diameter round brilliant diamond will weigh about 1.00 


\begin{tabular}{|c|c|c|c|c|c|c|}
\hline $\begin{array}{l}\text { Weight } \\
\text { (ct) }\end{array}$ & Equivalent color gradea & S.G. & $\begin{array}{l}\text { Long-wave UV } \\
\text { fluorescenceb }\end{array}$ & $\begin{array}{l}\text { Short-wave UV } \\
\text { fluorescence }\end{array}$ & $\begin{array}{c}\text { Luminescence } \\
\text { to X-rays }\end{array}$ & $\begin{array}{r}\text { Electrical } \\
\text { conductivity }\end{array}$ \\
\hline 1.12 & O-P (grayish green) & 3.22 & Wk. orange & Inert & nd & No \\
\hline 1.05 & M-N (grayish yellow) & 3.23 & Inert & Inert & nd & Yes \\
\hline 0.74 & U-V (gray) & 3.22 & Inert & Inert & nd & No \\
\hline 0.67 & S-T (greenish gray) & 3.22 & Inert & Inert & nd & No \\
\hline 0.66 & S-T (gray) & 3.21 & Inert & Inert & nd & No \\
\hline 0.57 & I-J (yellow) & 3.22 & Wk. orange & Inert & Wk. yellow & Yes \\
\hline 0.57 & M-N (gray) & 3.20 & Inert & Inert & nd & No \\
\hline 0.53 & K-L (green yellow) & 3.22 & Inert & Inert & Inert & Yes \\
\hline 0.53 & L-M (brownish yellow) & 3.21 & Inert & Inert & nd & No \\
\hline 0.44 & M-N (brownish yellow) & 3.22 & Inert & Inert & nd & Yes \\
\hline 0.43 & L-M (brownish yellow) & 3.24 & Inert & Inert & nd & Yes \\
\hline 0.35 & M-N (brownish yellow) & 3.21 & Inert & Inert & nd & Yes \\
\hline 0.33 & L-M (brownish yellow) & 3.22 & Inert & Inert & nd & Yes \\
\hline 0.33 & $\begin{array}{l}\text { M-N (greenish } \\
\text { brownish yellow) }\end{array}$ & 3.22 & Inert & Inert & nd & Yes \\
\hline 0.27 & J-K (yellow) & 3.23 & Inert & Inert & Inert & No \\
\hline 0.22 & L-M (green) & 3.21 & Mod. orange & Wk. orange & Mod. yellow & Yes \\
\hline 0.21 & S-T (gray) & 3.24 & Inert & Inert & Inert & No \\
\hline 0.20 & K-L (yellow) & 3.24 & Inert & Inert & Inert & No \\
\hline 0.19 & $\mathrm{nd}^{\mathrm{c}}$ & nd & Inert & Inert & Inert & No \\
\hline 0.10 & nd & nd & Inert & Inert & Inert & Yes \\
\hline 0.10 & nd & nd & Inert & Inert & Inert & Yes \\
\hline 0.09 & nd & nd & Inert & Inert & Inert & Yes \\
\hline 0.09 & nd & nd & Wk. orange & Inert & Inert & Yes \\
\hline
\end{tabular}

ct., whereas a synthetic moissanite of identical diameter and cut will weigh about $0.91 \mathrm{ct}$ ).

When examined with a desk-model spectroscope, the samples exhibited no sharp bands, but each displayed a cutoff below about $425 \mathrm{~nm}$. This is in contrast to near-colorless to light yellow diamonds, which usually show the "Cape" line at 415 $\mathrm{nm}$. This feature could be useful for gemologists with considerable spectroscopic experience, but it should be noted that it can be easy to confuse a 425 $\mathrm{nm}$ cutoff with the general darkening in the blue portion of the spectrum.
On all of the different thermal inertia instruments used for testing, every synthetic moissanite in this study registered as "diamond." Note that 13 samples displayed some electrical conductivity (unlike most near-colorless diamonds, although some light gray or blue diamonds are electrically conductive).

Microscopic Examination. When we examined the main sample of 23 synthetic moissanites with a microscope or loupe, we saw several distinctive characteristics. The most obvious feature seen
Figure 5. The synthetic moissanites examined at GIA ranged in color from approximately I to $U$ - $V$ on the GIA color-grading scale for diamonds. This range was most evident when the samples were placed table-down and viewed side-by-side in a white plastic tray, as illustrated here. All of the stones had a somewhat gray, green, or yellow appearance. The two largest samples shown here are 1.12 and $1.05 \mathrm{ct}$. Photo by Shane F. McClure.

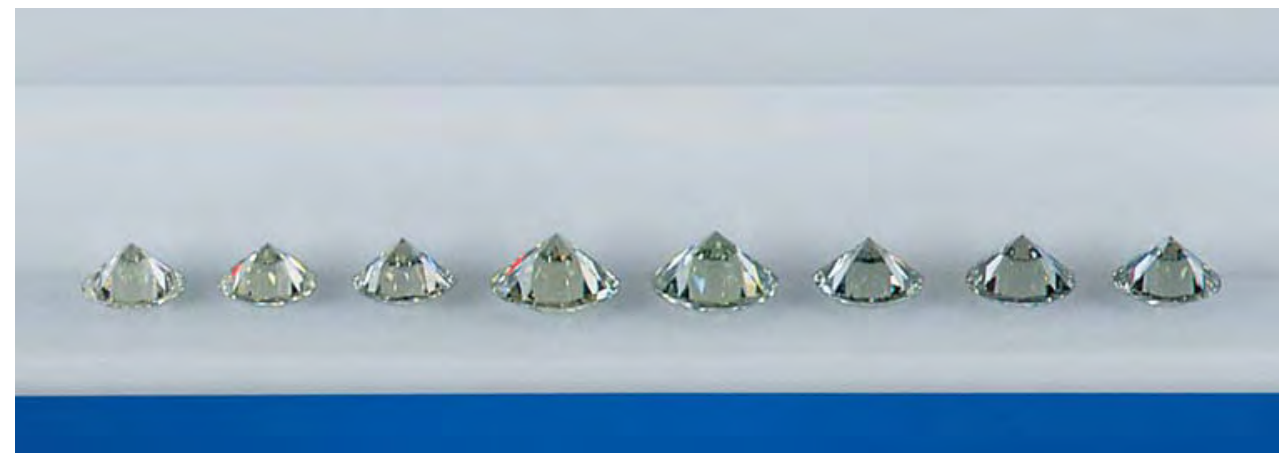



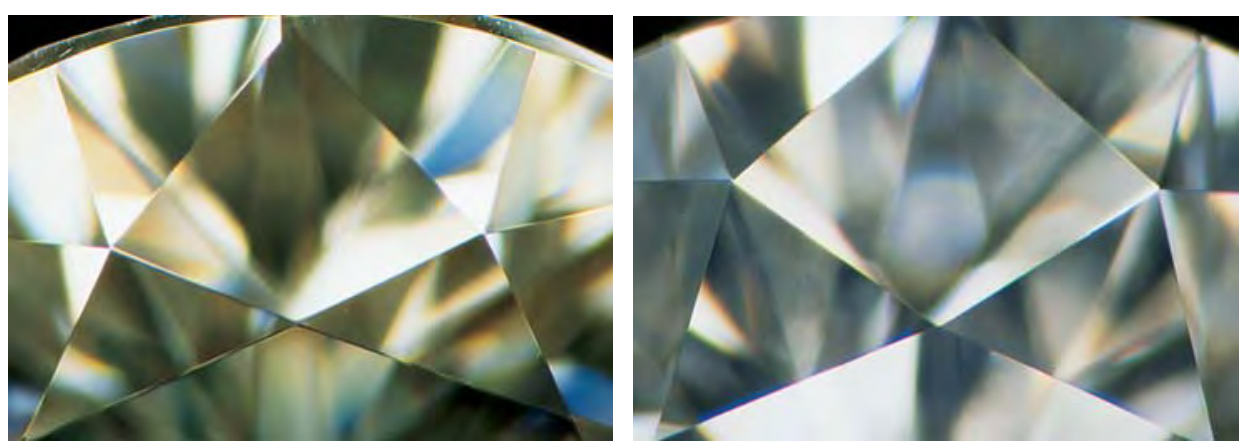

Figure 8. Most of the cut synthetic moissanites examined had somewhat rounded facet junctions (left), as compared to the sharp facet junctions of diamond (right).

Photomicrographs by

Shane F. McClure; magnified $34 x$.

any other materials, including synthetic moissanite. Therefore, if the polishing lines on individual facets (as observed in the microscope) all run in the same direction, the stone cannot be a diamond (figure 10). This test will not establish that the stone is synthetic moissanite, but in many instances just knowing it is not a diamond may be enough.

With magnification, we observed inclusions in almost all of the samples, although typically the samples were fairly clean. The most common inclusions were white-appearing needles that were subparallel to one another (see figure 11) and parallel to the c-axis (i.e., perpendicular to the table facet). Less prevalent, and somewhat less visible, were very fine, subparallel reflective stringers that were also oriented parallel to the c-axis (figure 12). These were best seen using fiber-optic illumination. Some samples contained scattered pinpoint inclusions, which in a few cases formed clouds. Several were large enough to resemble small crystals or gas bubbles when viewed with a loupe. We did not see fractures in any of the samples. On some facets, we saw cavities and/or smaller "whitish" pits or indentations with surrounding white-stained areas (see figure 13).

Figure 9. Parallel striations across the girdle of this synthetic moissanite readily separate it from diamond. Photomicrograph by Shane Elen; magnified 15x.

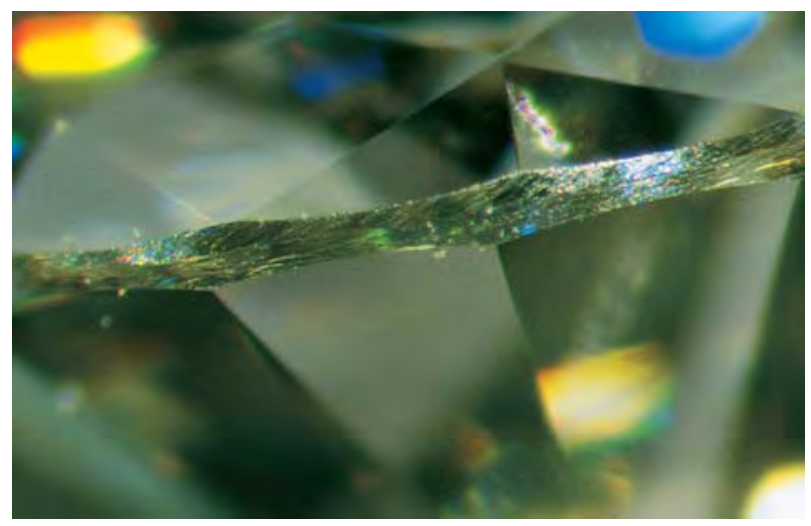

Quite unexpected, and apparently not previously reported for silicon carbide, were triangular pits that resemble the "trigons" characteristic of diamond crystal surfaces. One of the authors (KN) observed these on some samples of boules that he examined at $\mathrm{C} 3$. The pits range from less than a millimeter to $6 \mathrm{~mm}$ (figure 14) in longest dimension.

Fracture, Cleavage, and Twinning. Several cleavage directions have been reported in thin, hexagonal, carborundum-type plates of synthetic moissanite crystals (R.W. Keyes, in O'Connor and Smiltens, 1960). The possible cleavage of synthetic moissanite is significant not only because of the effect its presence would have on durability, but also because it would be another similarity to diamond.

To investigate whether cleavage was present in synthetic moissanite, we attempted to induce the reported cleavages in a $7 \mathrm{~mm}$ cube. When these attempts proved unsuccessful, we placed the cube on a steel plate and hit it several times with a large

Figure 10. Whereas the manufacturer must repeatedly adjust the polishing orientation for diamond because of its directional hardness, synthetic moissanite can be polished in a single direction. This is typically evident in the polishing lines on adjacent facets. Photo by Shane F. McClure; magnified 32x.

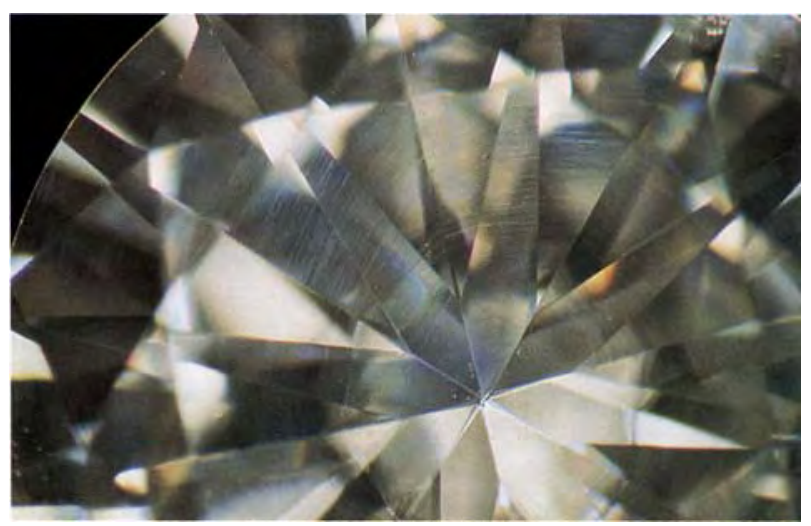


sponds to the region of absorption from 400 to 425 $\mathrm{nm}$ seen with a hand spectroscope. No sharp bands were recorded. In contrast, the spectra of near-colorless type Ia diamonds typically exhibit one or more sharp absorption bands of the "cape" series (with the most intense band being at $415 \mathrm{~nm}$ ); otherwise, they are increasingly transparent down to about $330 \mathrm{~nm}$ in the ultraviolet. Type Ila colorless diamonds lack these cape lines in their visible spectra.

The infrared spectra of the same eight synthetic moissanites again revealed identical features, with absorption below $1800 \mathrm{~cm}^{-1}$; several strong, sharp peaks between 2600 and $2000 \mathrm{~cm}^{-1}$; and several barely perceptible peaks between 3200 and 3000 $\mathrm{cm}^{-1}$ (figure 16). In contrast, the spectra of type Ia and IIa diamonds exhibit distinctly different characteristic sets of absorption features.

A Raman spectrum recorded for a polished cube of synthetic moissanite revealed a series of features that vary depending on the optical orientation of the sample. Nevertheless, the Raman spectra of synthetic moissanite are significantly different from those of diamond (figure 17).

The EDXRF spectra of the same eight samples showed the presence of silicon, a major constituent of synthetic moissanite, and no trace elements (figure 18). Note that carbon is not present in this spectrum because EDXRF does not detect light ele-

Figure 13. When viewed in reflected light, this small depression appears to be a white pit accompanied by a large stain. Photomicrograph by Shane Elen; magnified 20x.

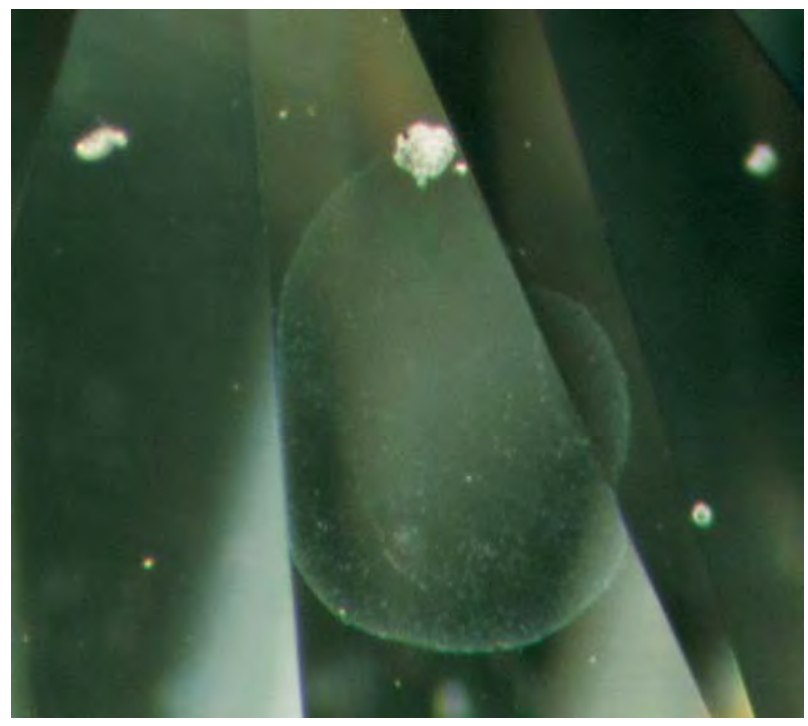

ments. Untreated natural diamonds do not exhibit $\mathrm{Si}$, although the presence of a silicon-containing mineral inclusion, such as garnet, could show up in the spectra. In the latter event, however, the inclusion would have to be so large that it was eyevisible.

Other Identification Tests. Because of the absorption below $425 \mathrm{~nm}$, synthetic moissanite is much less transparent in the ultraviolet region than nearcolorless diamond is. For example, it is more opaque than diamond when exposed to long-wave UV radiation. In terms of transparency to X-rays under the exposure conditions that render diamond more transparent, the synthetic moissanite appears more opaque. Both techniques allow several samples to be tested at the same time.

A previous study (Nassau and Schonhorn, 1977) published data on a "surface tension" test using the measurement of the contact angle of a drop of water on a facet as a means of identifying high-R.I. gem materials, and, in particular, separating diamonds from many colorless imitations. As reported in that study, diamond and synthetic moissanite have nearly the same contact angle; as a result, one cannot rely on either this test or use of a "diamond pen," which tests for this property.

Figure 14. This triangular pit on the surface of a 71.4 gram synthetic moissanite boule resembles one of the trigons commonly seen on diamond crystals. The pit has 6-mm-long sides and a depth of less than $0.25 \mathrm{~mm}$. Photo by K. Nassau.

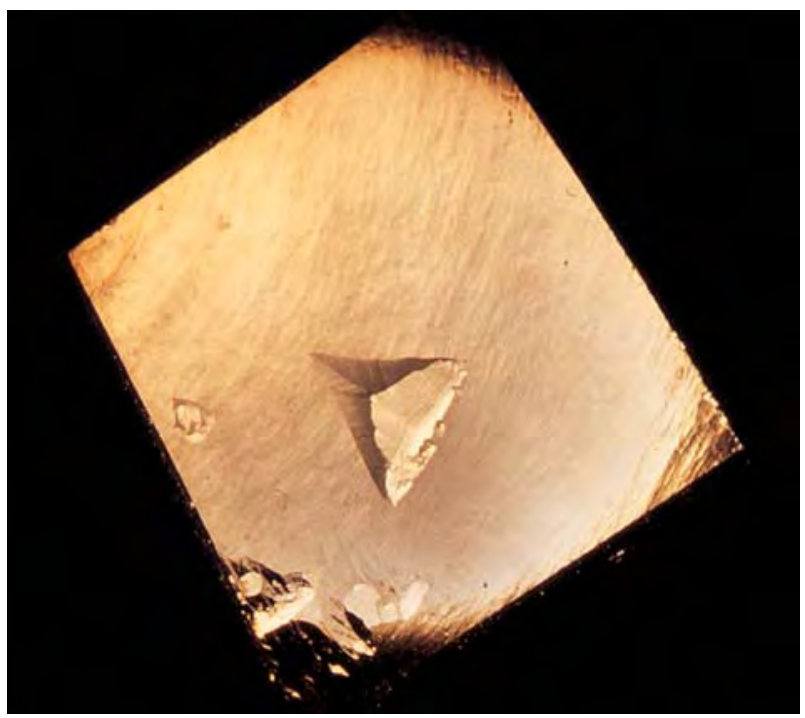




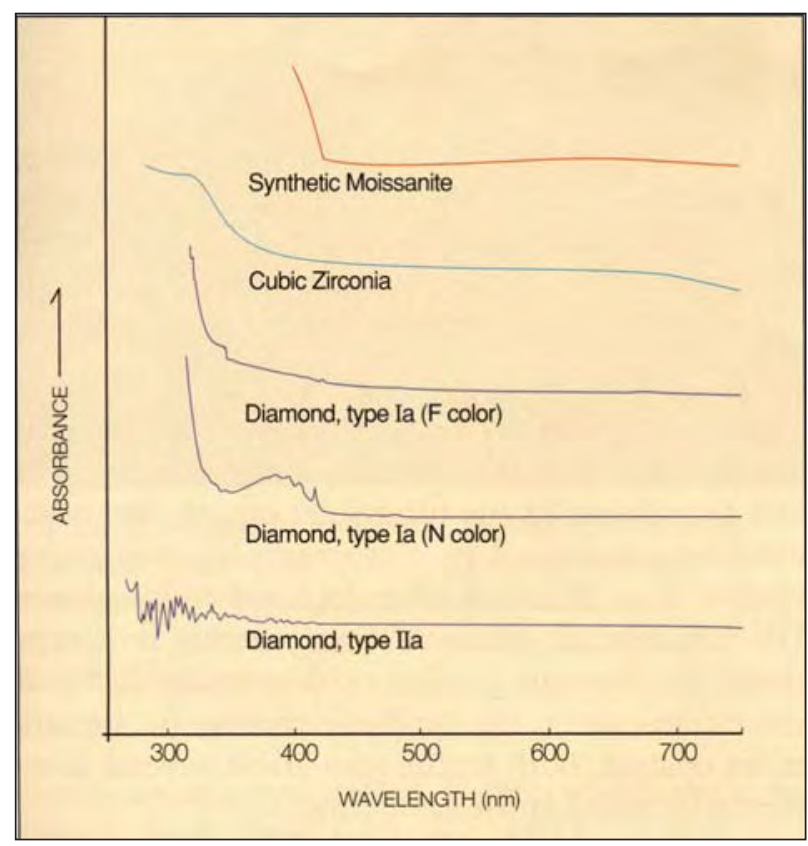

Figure 15. Illustrated here are the visible and nearultraviolet absorption spectra of a near-colorless synthetic moissanite, a colorless cubic zirconia, two type Ia diamonds, and a colorless type II a diamond. Note that the synthetic moissanite has no sharp bands, but does show a region of intense absorption beginning at about $425 \mathrm{~nm}$ and extending into the ultraviolet. It is this region of absorption, absent in the spectrum of diamond, that gives rise to the great difference in UV transparency between diamond and synthetic moissanite.

\section{DISCUSSION}

Synthetic moissanite is a believable imitation of diamond. However, it may exhibit slightly less brilliance; it has more dispersion, a lower S.G., and a higher R.I.; and it is less hard and nonisotropic. Nevertheless, diamond and synthetic moissanite have overlapping thermal inertia ranges, because of which they both react as "diamond" with a thermal probe.

The various gemological and other physical characteristics of the synthetic moissanites described in this article do not vary significantly from one sample to the next because the material is of fixed (i.e., stoichiometric) chemical composition, according to C3 Inc. (J. Hunter, pers. comm., 1997). (For the phase diagram of silicon carbide, see R. I. Scace and G. A. Slack in O'Connor and Smiltens, 1960.) Synthetic moissanite is a semiconductor material like diamond; the main differences in chemical composition in both materials involve only very small amounts of nitrogen and boron that can substitute in the crystal. This situation is quite different from cubic zirconia, where variable amounts of stabilizers, and even different stabilizers, lead to considerable variation in composition, and hence, to broad ranges in its properties.

Synthetic moissanite is reportedly stable in air to $1700^{\circ} \mathrm{C}\left(3092^{\circ} \mathrm{F}\right)$; in vacuum to $2000^{\circ} \mathrm{C}$; and is inert to well over $1000^{\circ} \mathrm{C}$ to most chemicals, except fluorine, chlorine, molten alkalis, and some molten metals (Divakar et al., 1993). In view of this high stability in air, even in situ soldering of broken prongs, as is done with diamond jewelry, should present no problem when synthetic moissanite is used in a mounting. In fact, the small synthetic moissanites in the 14k gold ring shown in figure 4 were cast in place, a practice used in manufacturing

Figure 16. The mid-infrared spectrum of synthetic moissanite is very different from the spectra of cubic zirconia and especially diamond.

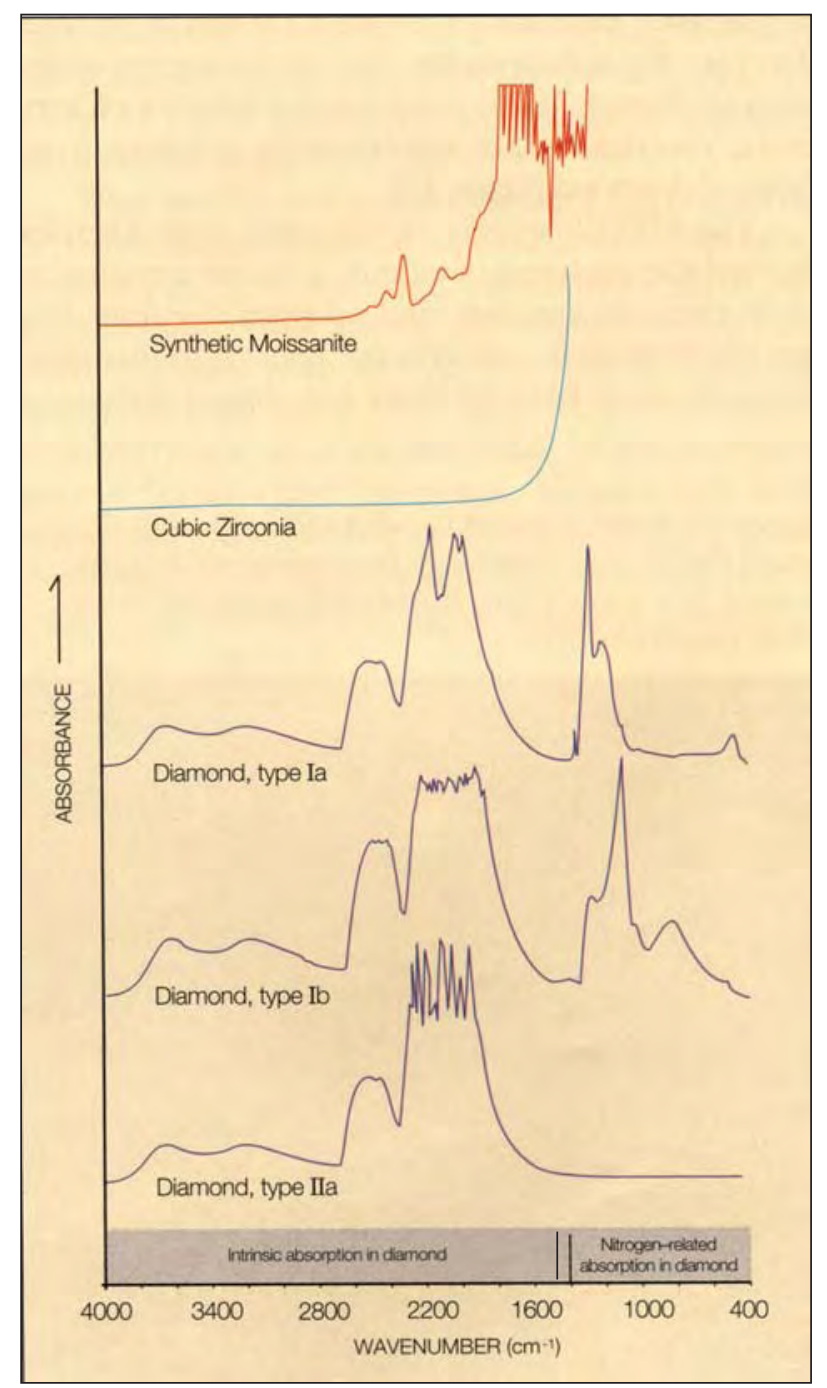


some commercial-quality jewelry, without any apparent damage to the samples. No durability testing was done during this study because no material was made available for this purpose. However, the manufacturer reports that no problems have arisen with conventional setting, repairing, and cleaning (J. Hunter, pers. comm., 1997).

Identifying Single Stones. Simple tests to separate synthetic moissanite from diamond include examination with a loupe or gemological microscope to look for double refraction (i.e., doubling of the facets). Distinctive subparallel needle-like inclusions and stringers oriented perpendicular to the table may be present, as well as rounded facet junctions, polishing lines that run in the same direction on adjacent facets, and an undiamond-like girdle appearance. Also, the synthetic moissanites in this

Figure 17. The $1332 \mathrm{~cm}^{-1}$ peak characteristic of diamond is absent in the Raman spectra of synthetic moissanite, regardless of orientation.

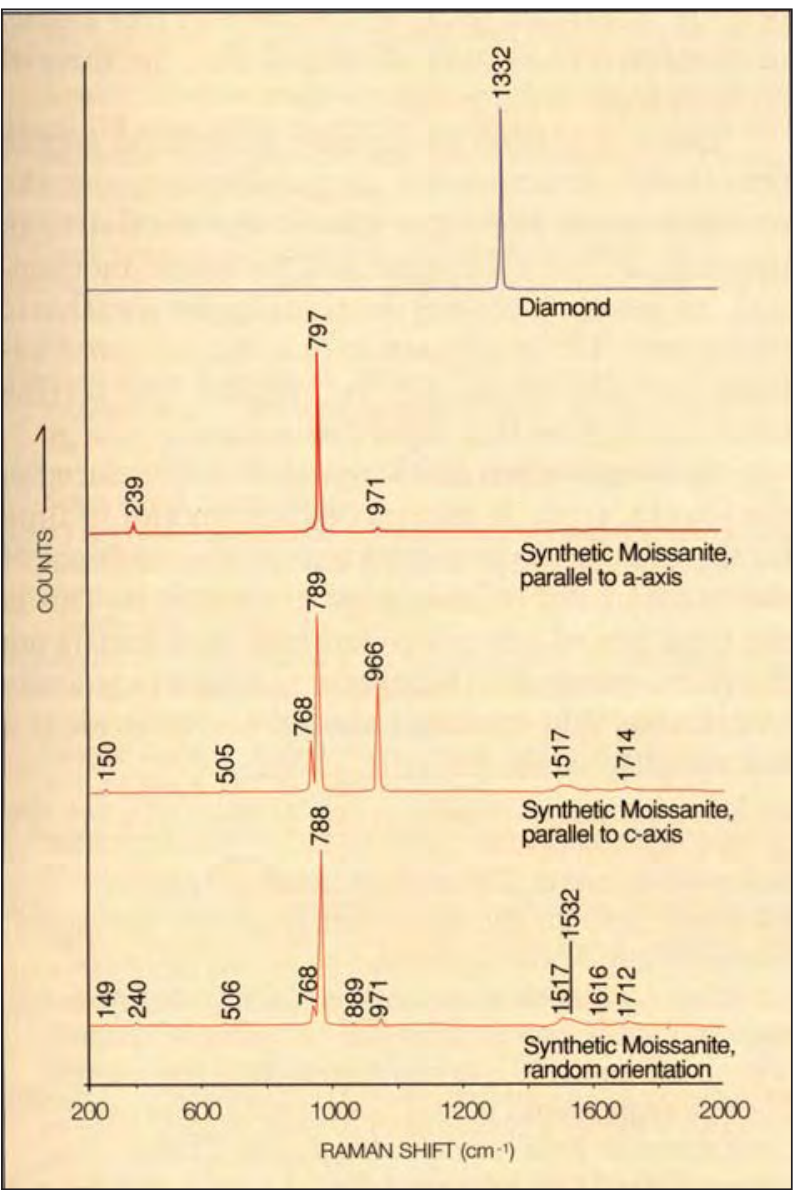




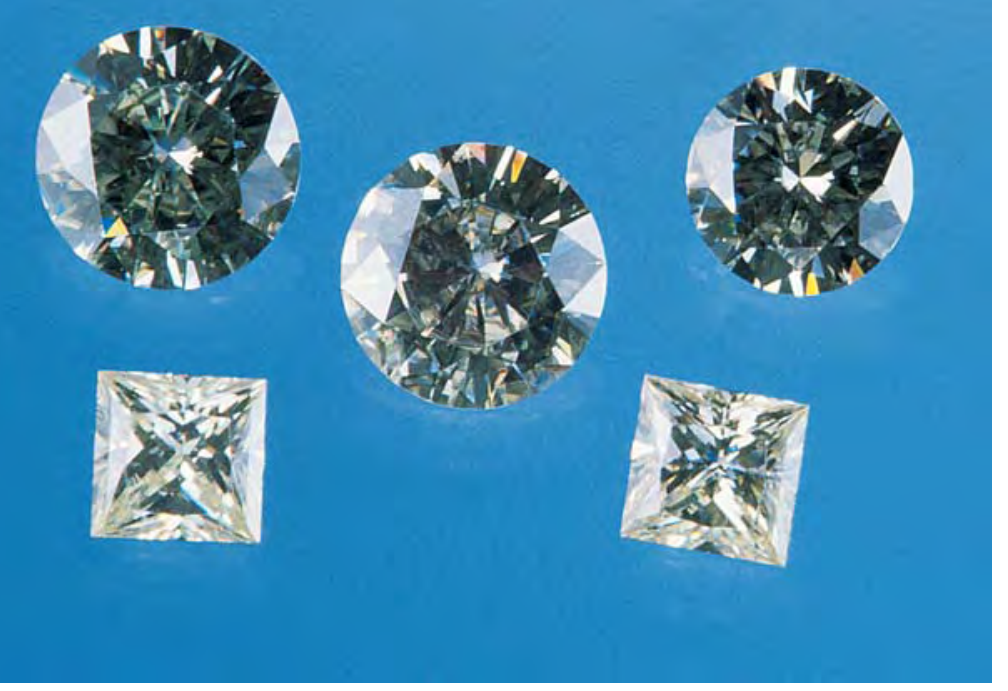

Figure 19. These round brilliants are the three largest synthetic moissanites studied at GIA. They ranged from 0.74 to $1.12 \mathrm{ct}$. The square modified brilliants represent some of the most attractive samples examined. Photo by Maha DeMaggio.

Identifying Synthetic Moissanite When Mixed with Other Stones. It may be necessary to separate synthetic moissanite from polished diamonds in a mixed parcel. One quick and reliable method is to use specific gravity, employing an appropriate heavy liquid (such as methylene iodide, S.G. 3.32): The less-dense synthetic moissanites will float, while the denser diamonds will sink (as always, care must be taken when handling heavy liquids due to their toxicity). Another approach is to take advantage of the great difference in near-ultraviolet and ultraviolet transparency, which offers a means to view a parcel of cut stones and separate them depending on whether they appear more transparent (diamond) or less transparent (synthetic moissanite).

\section{CONCLUSION}

Near-colorless synthetic moissanite soon could become widely available as a diamond imitation. Although no production figures are available yet, C3 Inc. has stated that it will begin marketing faceted stones to the trade early in 1998. Most of the samples examined for the main study were less than half a carat, but the authors did test three round brilliants ranging from 0.74 to $1.12 \mathrm{ct}$; other cutting styles were also available (figure 19).

The most readily identifiable gemological property of near-colorless synthetic moissanite is its double refraction. Care must be taken to look into the stone at an angle, or to focus the loupe or microscope past the culet to observe the reflections of the table and crown facets, since facet doubling is not usually evident in a sample face-up when viewed perpendicular to the table facet. Specific gravity is also diagnostic: Synthetic moissanite floats in 3.32 liquid, while diamond sinks. If an appropriate reflectivity meter is available, the difference in RI between diamond and synthetic moissanite will separate them as well (with proper precautions).

Features seen with magnification may be indicative, but they should be considered diagnostic only for the most experienced gemologist. Electrical conductivity is also indicative, but it should never be considered diagnostic.

It must be stated emphatically that the thermal inertia probes currently in wide use, which jewelers have relied on for many years to separate diamond from its simulants, must now be employed with great caution. Synthetic moissanite could be misidentified as diamond by a jeweler relying solely on these probes. Indeed, this has already been done experimentally, with the unfortunate results being televised in the United States on a news program that the Discovery Channel broadcast nationally on December 12, 1997. It is essential that the jeweler perform additional tests, as described in this article, to conclusively identify all stones that the thermal probe detects as diamond.

There is a need to develop additional simple gem-testing instruments, or possibly improve the existing thermal probes (given the similarity in thermal inertia of diamond and synthetic moissanite), to assist jewelers in testing for synthetic moissanite. The combination of a thermal probe followed by use of the C3 Inc. Model 590 testing instrument provides a rapid distinction.

As always when a new material is introduced to the jewelry trade, it takes a certain amount of time for the industry to become aware of the existence of the material and to learn how to identify it. This is the time period when jewelers and gemologists are the most vulnerable. Synthetic moissanite is easily identifiable, and mistakes should not be made if a few simple procedures are followed.

Acknowledgments: The authors thank Jeff Hunter, Thomas Coleman, and Earl Hines, of C3 Inc., Research Triangle Park, North Carolina, for making advanced samples of synthetic moissanite and the testing instrument available for study, and for providing information on this material, prior to its release to the market. The following helped provide gemological data on these samples: Bruce Lanzl, Chris Lewis, Cheryl Wentzell, Dr. Mary Johnson, John I. Koivula, Phil 
Owens, and Dino DeGhionno, all of the West Coast GIA Gem Trade Laboratory; as well as Jo Ellen Cole, Phil York, Carl Chilstrom, and other instructors of the GIA Education Department, Carlsbad, California.

\section{REFERENCES}

Acheson E.G. (1893) U.S. Patent 492,767, February 28, 1893.

Balaziak R. (1997) Manufactured abrasives in the third quarter of 1997. Mineral Industry Surveys, U.S. Department of the Interior, U.S. Geological Survey, Reston, VA.

Bruton E. (1978) Diamonds, 2d ed. Chilton Book Co., Radnor, PA.

Davis R.F., Carter C.H., Hunter C.E. (1990) Sublimation of Silicon Carbide to Produce Large, Device-Quality Single Crystals of Silicon Carbide. U.S. Patent Re. 34,861, February 14, 1995; reissue of U.S. Patent 4,866,005, September 12, 1989; reissue application filed October 26, 1990.

De Ment J. (1948) New gem superior to diamond. The Mineralogist, Vol. 16, pp. 211-218.

De Ment J. (1949) Silicon carbide-Rival to the diamond, in brilliancy. The Gemmologist (London), Vol. 17/18, pp. 53-59.

Divakar R., Chia K.Y., Kunz S.M., Lau S.K. (1993) Carbides (silicon): Silicon carbide. In M. Howe-Grant, Ed., Kirk-Othmer Encyclopedia of Chemical Technology, 3rd ed., John Wiley \& Sons, New York, Vol. 4, pp. 891-911.

GIA Gem Reference Guide (1988) Gemological Institute of America, Santa Monica, CA.

Hallbauer D.K., Kable E.J., Robinson D.N. (1980) The occurrence of detrital diamond and moissanite in the Proterozoic Witwatersrand conglomerates, and their implication for crustal evolution. Berliner Geowissenschaftliche Abhandlungen, Series A, Geologie und Paleontologie, Vol. 19, pp. 67-68.

Harris G.L., Ed. (1995) Properties of Silicon Carbide. Electronic Materials Information Service, Vol. 13, Institute of Electrical Engineers (INSPEC), London.

Hobbs J. (1981) A simple approach to detecting diamond simulants. Gems «) Gemology, Vol. 17, No.1, pp. 20-33

Hoover D.B. (1983) The Gem DiamondMaster and the thermal properties of gems. Gems \&) Gemology, Vol. 19, No. 2, pp. 77-86.

Johnson M.L., Koivula J.I., Eds. (1996) Gem news: Synthetic moissanite as a diamond simulant. Gems \&) Gemology, Vol. 32, No. 1, pp. 52-53.

Kunz G.F. (1905) "Moissanite." American Journal of Science, Series 4, Vol. 19, pp. 396-397.

Lely J.A. (1955) Darstellung von Einkristallen von Silicium-carbid und Beherrschung von Art und Menge der eingebauten Verunreinigungen. Berichte der Deutschen Keramischen Gesellschaft, Vol. 32, pp. 229-231.

Mason B. (1962) Meteorites. John Wiley \& Sons, New York, p. 61.

Mathez E.A., Fogel R.A., Hutcheson I.D., Marshintsev V.K. (1995) Carbon isotopic composition and origin of $\mathrm{SiC}$ from kimberlites of Yakutia, Russia. Geochimica et Cosmochimica Acta, Vol. 59, No. 4, pp. 781-791.

McCawley E.L. (1981) Cubic moissanite-a gem mineral of the diamond family. Lapidary Journal, Vol. 34, No. 10 (January), pp. $2244-2247$.

Mellor C. (1929) A Comprehensive Treatise on Inorganic and Theoretical Chemistry. Longmans, Green \& Co., London, Vol. 5, pp. 875-887.

Milton C. (1986) Moissanite SiC: Yes or no? Fourteenth General Meeting, International Mineralogical Association, Abstracts, Stanford University, Stanford, CA, p. 171.

Milton C., Vitaliano D. (1984) Moissanite SiC: A non-existent mineral. Twenty-Seventh International Geological Congress, Abstracts, Moscow, p. 89.

Mitchell R.K. (1962) A rare synthetic. Journal of Gemmology, Vol. 8, No. 6, pp. 218-220.
Moissan F.F.H. (1904) Étude de la meteorite de Canyon Diablo. Comptes Rendus de Academie des Sciences, Paris, Vol. 139, p. 773.

Moore R.O., Otter M.L., Rickord R.S., Harris J.W., Gurney J.J. (1986) The occurrence of moissanite and ferro-periclase as inclusions in diamonds. Fourth International Kimberlite Conference, Abstracts, Sydney, Geological Society of Australia, pp. 409-411.

Nakashima S., Matsunami H., Yoshida S., Harima H., Eds. (1996) Silicon carbide and related materials. Proceedings of the Sixth International Conference, Kyoto, September 18-21, 1995, Conference Series No. 142, Institute of Physics Publishing, Philadelphia, PA.

Nassau K. (1980) Gems Made by Man. Gemological Institute of America, Santa Monica, CA.

Nassau K., Schonhorn H. (1977) The contact angle of water on gems. Gems ef Gemology, Vol. 15, No. 12, pp. 354-360.

Obukhov A.B. (1972) Mineralogy of Silicon Carbide: Silicon Carbide in Technical Materials and Rocks (in Russian). Akademia Nauk SSSR, Leningrad, 140 pp.

O'Connor J.R., Smiltens J. (1960) Silicon Carbide: A High temperature semiconductor. Proceedings of the Conference on Silicon Carbide, Boston, MA, April 2-3, 1959, Pergamon Press, New York.

Powell B.W. (1956) The story of silicon carbide. Lapidary Journal, Vol. 10, No. 5, pp. 430-438.

Ramsdell L.S. (1947) Studies of silicon carbide. American Mineralogist, Vol. 32, No. 1/2, pp. 64-82.

Rodgers K.A., Courtney S.F., Seelye R., McCullock A., Mulholland I. (1989) An occurrence of "moissanite" (SiC) from Seddonville, West Coast, New Zealand. New Zealand Natural Sciences, Vol. 16, pp. 105-108.

Smoak R.H., Korzekwa T.M., Kunz S.M., Howell E.D. (1978 Carbides: Silicon Carbide. In D. Eckroth, Ed., Kirk-Othmer Encyclopedia of Chemical Technology, 3rd ed., John Wiley \& Sons, New York, Vol. 4, pp. 520-535.

Tairov Y.M., Tsvetkov V.F. (1981) Growing large-size, single crystals of various silicon carbide polytypes. Journal of Crystal Growth, Vol. 52, pp. 146-150.

Thibault N.W. (1944) Morphological and structural crystallography and optical properties of silicon carbide (SiC). American Mineralogist, Vol. 29, No. 7/8, pp. 249-278, and No. 9/10, pp. 327-362.

Tsvetkov V.F., Allen S.T., Kong H.S., Carter C.H. Jr. (1996) Recent progress in $\mathrm{SiC}$ crystal growth. In $\mathrm{S}$. Nakashima, $\mathrm{H}$. Matsunami, S. Yoshida, and H. Harima, Eds., Silicon Carbide and Related Materials. Proceedings of the Sixth International Conference, Kyoto, September 18-21, 1995, Conference Series No. 142, Institute of Physics Publishing, Philadelphia, PA.

Verma A.R., Krishna P. (1966) Polymorphism and Polytypism in Crystals. John Wiley \& Sons, New York.

Vigorova V.G., Chashchukhina V.A., Vigorov B.L., Palguyeva G.V. (1978) Moissanite from granite of the Urals. Doklady Akademia Nauk SSSR, Earth Science Sections,Vol. 241, pp. 182-185.

von Muench W. (1982) Silicon carbide. In O. Madelung, Ed. Landolt-Boernstein Numerical Data and Functional Relationships in Science and Technology, New Series, Group III, Vol. 17A, Springer Verlag, New York, pp. 132-142, 442-449.

von Muench W. (1984) Silicon carbide. In M. Schultz and H. Weiss, Eds., Landolt-Boernstein Numerical Data and Functional Relationships in Science and Technology, New Series, Group III, Vol. 17C, Springer Verlag, New York, pp. 403-416, 585-592.

Wilke K.-Th. (1988) Kristallzuechtung. Verlag Harri Deutsch, Thun, Frankfurt.

Yu R.M., Healey D. (1980) A phosphoroscope. Journal of Gemmology, Vol. 17, No. 4, pp. 250-258. 